\title{
The Political Economy of Reserve Accumulation in the Developing World
}

\author{
H an, Intaek \\ (Ewha Womans University)
}

$\langle$ CONTENTS〉

I. Introduction

II. Reserve Accumulation: Trend and Explanations

1. Economic Explanations:

Precaution vs. Mercantilism

2. Political and Institutional

Explanation: Democracy and

Representation in the IMF
III. Empirical Analysis

1. Data and Variables

2. Results

IV. Conclusion

- Keyword: reserve hoarding, global capital flows paradox, democracy, IMF representation, developing countries.

\section{【ABSTRACT】}

A significant, but little-analyzed, recent trend in the developing world is official reserve hoarding. Though conspicuous and socially costly, this phenomenon has largely escaped the attention of political scientists. This paper is a first step towards understanding political and institutional factors that drive reserve accumulation. A cross-sectional analysis of non-OECD countries shows that democratic countries are more likely to have high official reserve balances than authoritarian countries, and also that countries that are under-represented in the IMF accumulate larger reserves than countries that are well represented. The results suggest that both economics and politics play an important role in reserve accumulation in the developing world. 


\section{I . Introduction}

A significant, but little-understood, new phenomenon in the developing world is official reserve hoarding, which has risen on an unprecedented scale. Let us consider South Korea, for instance. The country's GDP in 2005 was estimated to be 801.2 billion dollars. Its official reserves, as of October 2006, are 229.5 billion dollars - more than one fourth of the size of its GDP. Contrast this with the meager 7 or 8 billion dollars it reportedly had as actually usable reserves at the height of the 1997 crisis. Clearly, South Korea has come a long way since then. The Korean experience is by no means unique, however. As Table 1 shows, developing countries, as a whole, have increased their holdings of foreign exchange reserves by more than five times since 1990, while developed countries have failed to increase their official reserves even twofold.

$\langle$ Table 1〉 Official Foreign Exchange Reserves (\$ billion)

\begin{tabular}{l|c|c|c|c|c}
\hline & 1990 & 1993 & 1996 & 1999 & 2002 \\
\hline Developing Countries & 308.3 & 503.1 & 816.6 & 1041.3 & 1693 \\
\hline Industrialized Countries & 481.7 & 459.8 & 681.1 & 704.7 & 900 \\
\hline World & 790 & 962.9 & 1497.7 & 1746 & 2593 \\
\hline
\end{tabular}

Source: Financial Markets Center, Capital Flows Monitor; B. Setser, Global Reserve Watch

What explains this unprecedented surge in the official reserves kept by developing nations? This paper aims to contribute to the search for the causes of reserve buildup in the developing world by exploring political and institutional factors that have been sidelined thus far. As this paper will show, democratic countries are more likely to hold high official reserve balances than authoritarian countries; countries that are underrepresented in the IMF accumulate larger foreign exchange reserves than countries that are well represented.

\section{II . Reserve Accumulation: Trend and Explanations}

Official reserves refer to "all the assets of monetary authorities that can be used, directly or through assured convertibility into other assets, to support its rate of exchange when its external payments are in deficit." ${ }^{1)}$ They are usually made of gold,

1) J. Horne and D. Nahm, "International Reserves and Liquidity: A Reassessment." Macquarie Economics Research Paper 5 (2000), p.9. 
SDRs, and reserve currencies. The US dollar is particularly important as a reserve currency, with more than $60 \%$ of the world's total reserves being in US dollars or US Treasuries.

Under the Bretton Woods system of fixed exchange rates, monetary authorities needed official reserves to manage fixed exchange rates. Since the collapse of the Bretton Woods currency regime in the early 1970s, many countries have switched to more flexible exchange-rate arrangements, officially freeing themselves from the burden of maintaining fixed exchange rates. In theory, flexible exchange-rate arrangements require smaller international reserves than fixed exchange-rate arrangements. Table 2 shows, however, that the collapse of the Bretton Woods currency regime did not have the expected effect. Developing countries' official reserve holdings grew larger, not smaller, after the breakdown of the Bretton Woods system. The table also shows that the scale and pace of reserve accumulation have been by no means universal, or uniform, across regions and decades.

〈Table 2〉 Reserve Holdings as a Share of GDP by Decade and Region

\begin{tabular}{l|c|c|c|c}
\hline \multicolumn{1}{c|}{ Region } & 1960 's & 1970 's & 1980 's & 1990 's \\
\hline East Asia and Pacific & $12.2 \%$ & $16.2 \%$ & $19.4 \%$ & $22.5 \%$ \\
\hline South Asia & $4.1 \%$ & $6.3 \%$ & $8.1 \%$ & $8.4 \%$ \\
\hline Latin America and the Caribbean & $5.0 \%$ & $9.1 \%$ & $8.9 \%$ & $11.8 \%$ \\
\hline Sub-Saharan Africa & $5.7 \%$ & $7.6 \%$ & $7.4 \%$ & $11.7 \%$ \\
\hline Middle East and North Africa & $10.9 \%$ & $14.0 \%$ & $24.2 \%$ & $21.4 \%$ \\
\hline
\end{tabular}

Source: D. Baker and K. Walentin, "Money for Nothing: The Increasing Cost of Foreign Reserve Holdings for Developing Nations," Center for Economic and Policy Research, 2001, p.5.

Developing countries' reserve accumulation is puzzling on at least two grounds. First, the level of reserves held by monetary authorities in many developing countries is excessive even by the strictest criteria proposed so far. $\left.{ }^{2}\right)$ Table 3 shows excess reserves held by selected developing countries. Their reserve balances were determined excessive not by some outdated standard but by one of the newest and widely-respected standards: the Greenspan-Guidotti rule that reserves should equal one year's shortterm debt. Not only are excessive reserves substantial-in some cases, over $60 \%$ of GDP-but they are also not limited to any one region or type of economy. Second, excessive reserves indicate that a historically unprecedented pattern of capital export

2) L. Summers. "Reflections on Global Account Imbalances and Emerging Markets Reserve Accumulation." L.K. Jha Memorial Lecture, Reserve Bank of India, India, 2006.

http://www.president.harvard.edu/speeches/2006/0324_rbi.html (Access date: October 2006). 
has emerged: Developing countries are now exporting capital to developed countriesprincipally to the United States - by financing developed countries' public debts." This phenomenon, which L. Summers calls the global capital flows paradox, is not only unsustainable in the long run but also economically unhealthy. The United States cannot borrow from developing countries indefinitely; when the flow of capital from developing countries stops one day, the US economy is likely to experience a hard landing, which is by no means encouraging news for the world economy.

〈Table 3〉 Excess Reserves beyond the Greenspan-Guidotti Rule (3rd Quarter 2005)

\begin{tabular}{l|c|c}
\hline \multicolumn{1}{c|}{ Country } & Excess Reserves (\$ millions) & Excess Reserves (\% of 2004 GDP) \\
\hline China & 724,080 & $41 \%$ \\
\hline Taiwan & 210,134 & $69 \%$ \\
\hline South Korea & 136,711 & $18 \%$ \\
\hline Russia & 118,154 & $20 \%$ \\
\hline India & 107,703 & $15 \%$ \\
\hline Malaysia & 58,613 & $50 \%$ \\
\hline Algeria & 50,518 & $60 \%$ \\
\hline Mexico & 47,083 & $7 \%$ \\
\hline Thailand & 35,489 & $21 \%$ \\
\hline Saudi Arabia & 73,897 & $29 \%$ \\
\hline
\end{tabular}

Source: Lawrence Summers, "Reflections on Global Account Imbalances and Emerging Markets Reserve Accumulation," 2006.

Excessive reserves would be a less serious problem if holding them did not carry a substantial cost. The fact is, however, that holding reserves is costly. They are particularly costly for developing countries because by holding foreign currencies as reserves, developing countries are essentially foregoing opportunities to spend them on higher-yield investments. ${ }^{4)}$ The combined opportunity cost of holding excessive reserves for the countries in Table 2 is close to 2 percent of their GDP. In addition, the cost of excessive reserve holdings increases even further if the U.S. dollar depreciates, as most

3) Summers (2006). See also M. Higgins and T. Klitgaard. "Reserve Accumulation: Implications for Global Capital Flows and Financial Markets." Current Issues in Economics and Finance 10 (September/October 2004), pp.1-7.

4) D. Hauner. "A Fiscal Price Tag for International Reserves." IMF Working Paper WP/05/81 (April 2005); D. Rodrik. "The Social Cost of Foreign Exchange Reserves." Paper prepared for presentation at the American Economic Association meetings in Boston, January 2006; D. Baker and K. Walentin. "Money for Nothing: The Increasing Cost of Foreign Reserve Holdings to Developing Nations." Center for Economic and Policy Research (2001). 
developing countries hold U.S. dollars or US Treasuries as reserves.

Why, then, do developing countries hoard reserves? The primary permissive cause for the rise of official reserve holdings is the persistent balance-of-payments deficits by the United States. A balance of payments surplus with the U.S., however, does not automatically increase a developing country's official reserves. Income from trade in goods and services, or from financial transactions, only increases private sector agents' holdings of foreign currencies and assets. Privately-held foreign currencies and assets are different from official reserves; before they can be added to official reserves, they must first be acquired by monetary authorities. Monetary authorities, however, differ widely in their willingness and capability to acquire them as reserves, which is basically what Tables 2 and 3 tell us. Thus, neither the systemic change (the collapse of the Bretton Woods currency regime), nor the supply factor (U.S. deficits), provides an adequate explanation for the scale of, and variations in, developing countries' reserve hoarding. We, therefore, need to pay closer attention to the characteristics of individual countries.

\section{Economic Explanations: Precaution vs. Mercantilism}

Countries with a large economy are likely to hold larger reserves than countries with a small economy. Countries are also thought to increase reserve holdings when they adopt fixed exchange-rate systems, or when they lift capital control. Such conventional explanations are, however, insufficient when one wants to make sense of excessive reserve hoarding in the developing world. Lately, two new explanations have been proposed to explain the reserve hoarding behavior of developing countries, each emphasizing a different motive for the building up of reserves. ${ }^{5}$ The "precautionary demand" explanation posits that hoarding international reserves is best viewed as selfinsurance against possible costly output contractions caused by liquidity shocks, such as the Asian financial crisis. According to this view, monetary authorities hoard reserves in preparation for financial market instability. ${ }^{6)}$ This view has gained growing acceptance in the aftermath of the Asian financial crisis and the rapid build-up of international reserves in East Asia that followed. The "mercantilist" explanation, on the other hand, views reserve hoarding as an export-promotion strategy. ${ }^{7)}$ This view places

5) See among others J. Aizenman and J. Lee. "International Reserves: Precautionary vs. Mercantialist Views, Theory and Evidence." IMF Working Paper WP/05/198 (October 2005).

6) G. Bird and R. Rajan. "Too Good to be True?: The Adequacy of International Reserve Holdings in an Era of Capital Account Crises” CIES Discussion Paper 0210 (Australia: University of Adelaide, 2002). 
reserve management within a larger context of national development strategy; it posits that developing countries accumulate excessive reserves in order to prevent or slow currency appreciation, and to facilitate export-led growth. Amid the widespread criticism that China keeps its currency artificially undervalued, support for the mercantilist explanation is also growing.

These explanations are not mutually exclusive. Developing countries may hoard international reserves both as self-insurance and as export-promotion strategy. Also, since the two explanations have been inspired principally by the experience of East Asian countries, it is only natural that one finds support for each theory in East Asian countries. This also means that testing the two explanations requires studying reserve hoarding behavior outside East Asia, since one may not use the same case to derive and test a theory. So far, attempts to empirically test the two explanations on non-East Asian cases have been limited. One significant obstacle that researchers face in testing the hypotheses is the difficulty of measuring the precautionary demand and the mercantilist impulse directly and precisely. We need improved measurement before we can be certain that precaution and mercantilism are indeed the main driving forces behind the phenomenal increase in reserve holdings. Consequently, while the two explanations offer promising new ways to look at the extraordinary rise in reserve holdings in the developing world, it is accurate to say that they are still tentative hypotheses that have not been rigorously tested.

\section{Political and Institutional Explanation: Democracy and Representation in the IMF}

Over the past few decades, political scientists have proposed explanations for various events and decisions in the areas of international money and finance. ${ }^{8)}$ There are now, for instance, a small but increasing number of political science studies that explain capital decontrol, exchange rate regime choice, or speculative attacks. The rise in developing countries' reserve holdings, however, has largely escaped the attention of political scientists. ${ }^{9)}$ This is intriguing, given the fact that reserve hoarding is conspicuous and socially costly, and also given that developing countries' reserve

7) For an example of the mercantilist view on China's reserve holdings, see J. Dean and R. Rajan. "Why and Whither China's Reserves?: Motives, Costs, Consequences and Putative Policies." manuscript (2004), p.4.

8) For a broad overview, see J. Broz and J. Frieden. "The Political Economy of International Monetary Relations." Annual Review of Political Science 4 (2001), pp.217-343. 
hoarding has attracted the attention of many economists.

In explaining events or decisions in international money and finance, political scientists do not deny the importance of economic factors. Rather, after identifying political and institutional factors of causal importance, they show how such factors operate hand-in-hand with economic factors. Thanks to their research, a great deal is now known about how such factors as partisanship, elections, and institutions affect decisions regarding capital control and exchange-rate regimes, or even the chances of speculative attacks. Little is known, however, about political and institutional factors behind developing countries' excessive reserve hoarding. Indeed, no identifiable political science literature exists on this subject.

Given the dearth of political science literature concerning official reserve management, the selection of key political and institutional factors in this paper is guided by the literature on a closely related subject, exchange rate regime choice, and also by ongoing discussions about developing countries' representation in the International Monetary Fund.

\section{(1) Democracy}

The literature on exchange rate regime choice is particularly relevant for our research because both in managing official reserves and in choosing exchange rate regimes, the same set of actors - monetary authorities, financiers, and traders - participate and pursue essentially the same policy objectives - stability, competitiveness, or creditworthiness — via official reserve management and exchange rate regime choice. ${ }^{10)}$ In other words, official reserve management and exchange rate regime choice have many commonalities, in terms of participants, preference, policy processes, and environments.

One important finding of the exchange rate regime choice literature is that there is a clear relation between a developing country's political regime and the type of exchangerate regime that the country is likely to adopt. Leblang puts this point succinctly when he states, "In sum, policymakers in democratic countries are more likely than their counterparts in authoritarian countries to adopt floating exchange rate regimes." ${ }^{11}$ As for the reason why this is the case, Leblang explains that the pressure for distributive

9) To this author's knowledge, there is no published work on this topic in the political science literature at time of this writing.

10) Frieden focuses on societal preference for exchange rate policy, while Bernhard and Leblang highlight politicians' preference. J. Frieden. "Invested Interests: The Politics of National Economic Policy in a World of Global Finance." International Organization 45 (1991), pp.425-51.;W. Bernhard and D. Leblang. "Democratic Institutions and Exchange Rate Commitments." International Organization 53 (1999), pp.71-97. 
and expansionary policy increases under democracy because diverse groups are included in the policymaking and electoral process. Faced with such pressure, a floating exchange rate regime is preferable for politicians since it allows them to direct monetary policy towards domestic objectives instead of the maintenance of the exchange rate.

The same reasoning can be applied to official reserve management as well. In the analogous manner that a floating exchange rate regime gives policymakers larger room to maneuver monetary policy for political advantages than a fixed exchange-rate regime, larger reserves give policymakers larger room to maneuver monetary policy and exchange-rate policy for political advantage than smaller reserves. Under capital mobility, monetary policy and exchange rate policy are closely interlinked. ${ }^{12)}$ One cannot normally implement an expansionary monetary policy without affecting the exchange rate. Thus, for fear of exchange rate volatility, or of reneging on their commitment to an exchange-rate arrangement, politicians often give up monetary policy autonomy. The reason, according to J. Sachs et al., is that governments that renege on exchange-rate commitments face costs, including "loss of pride, voter disapproval, maybe even removal from office." ${ }^{13)}$

Large reserves, especially excessively large reserves, open a window for politicians to pursue relatively autonomous monetary policy, without having to worry too much about exchange rate volatility or breaking the commitment to an exchange-rate system. Of course, this does not mean that with large reserves politicians are free to pursue expansionary monetary policy in any way they like. It simply means that, with large reserves, they are relatively freer to purse autonomous monetary policy that would benefit them politically, since with excessive reserves policymakers can intervene in the foreign-exchange market to defend the currency if necessary; more generally, large reserves serve as a buffer against exchange-rate volatility. Politicians running for office would appreciate such benefits, especially since the cost of holding large reserves is borne by society, not by themselves. Additionally, politicians may prefer larger reserve balances, simply because of the perception, whether accurate or not, that larger reserves symbolize successful economic management. In other words, the larger the

11) D. Leblang. "Domestic Political Institutions and Exchange Rate Commitments in the Developing World." International Studies Quarterly 43 (1999), p.605.

12) B. Cohen. "The Triad and the Unholy Trinity: Lessons for the Pacific Region," in R. Higgott, et. al. (eds.), Pacific Economic Relations in the 1990s: Conflict or Cooperation? (Boulder, CO: Lynne Rienner, 1993).

13) J. Sachs, et. al. "Financial Crises in Emerging Markets: The Lessons from 1995" Brookings Papers on Economic Activity 1 (1996). Originally quoted in D. Leblang. "To Devalue or to Defend? The Political Economy of Exchange Rate Policy.” International Studies Quarterly 47 (2003), p.538. 
reserve balances, the better the standing of national policymakers vis-à-vis their constituents and ultimately, their opponents.

\section{(2) Representation in the IMF}

An IMF quota is the amount of financial resources each country provides to the Fund when it joins the Fund. ${ }^{14)}$ Because larger quotas translate into larger financial obligations to the Fund, one may think countries would prefer smaller quotas. However, this is not usually the case for several reasons. First, while a country must pay $25 \%$ of its quota in SDRs, or in reserve currencies such as the U.S. dollar, the rest can be paid in the country's own currency. As a result, countries may find their financial obligations to the Fund less burdensome. Secondly, the allocation of votes among members is based on the size of their quotas. Thus, having a larger quota increases a country's potential to influence the IMF's decision-making, even though the relationship between the number of votes and actual influence over decision-making is often not very linear. Thirdly, the ability of a country to access the Fund's financial resources is determined by the size of the country's quota. Under Stand-By and Extended Arrangement, which is designed to help countries having balance-of-payments problems, a member can borrow up to $100 \%$ of its quota annually, not exceeding 300\% cumulatively. Therefore, a country's quota determines its ability to borrow-the larger a country's quota, the greater its ability. Lastly, SDRs, international reserve assets created by the IMF, are allocated to member countries in proportion to their quotas. SDR allocations increase member countries' reserves essentially without incurring them any costs.

Given the importance and benefits of IMF quotas, it is not unexpected that developing countries, especially emerging market economies, will attempt to increase their quotas. Their efforts are, however, only varyingly successful. Developed countries, which already have large quotas, do not have a strong need to increase their quotas. Perhaps more important from a political point of view, they generally do not want developing countries' quotas to increase unless their own quotas increase as well; otherwise, their voice in the IMF is likely to decrease, as votes are allocated in proportion to quotas.

One should not, however, assume from the above discussion that developing countries are uniformly under-represented in the IMF. Among developing countries, the degree of under-representation differs. In fact, Rapkin and Strand find that many developing countries are actually over-represented under the current quota system, while others

14) On the role, determination, and implications of quotas for developing countries, see D. Rapkin and J. Strand. "Developing Country Representation and Governance of the International Monetary Fund." World Development 33-12 (2005). 
are under-represented. ${ }^{15)}$ In other words, many developing countries' quotas and voting weights within the IMF are larger than their share of the global GDP, while other developing countries' quotas and voting weights are smaller than their share of the global GDP. ${ }^{16)}$

In explaining reserve hoarding, would it matter how a developing country is represented in the IMF? Under-representation would be troublesome for any country, but it would be more troublesome for a developing country than for a developed country because developing countries are more likely to run into balance-of-payments problems. In addition, when they do experience balance-of-payment problems, they cannot rely on international financial markets to supplement their reserves as easily as developed countries can. So for developing countries, IMF support is particularly critical, and it is important that their quotas and votes are not proportionally smaller than their economic size. Also, aside from such economic considerations, countries would want the number of their votes in the IMF to be congruent with their relative economic position in the world. This is because IMF votes are supposed to be allocated according to a country's relative standing in the global economy. Thus, any country that has received fewer votes than they deserve, based on the size of their economy, would feel unfairly treated.

What would developing countries do if they found themselves under-represented against their wishes? If we assume that reforming the existing quota system is not a practical option for developing countries, they are likely to make up for smaller quotas by accumulating international reserves. This is out of economic, as well as positional, interests. Under-represented countries would hoard reserves to make up for their quotas - which are small relative to their economy - for financial stability; they would also hoard reserves because larger reserves often symbolize a stronger economy, and draw international respect. Thus, other things being equal, the more under-represented a nation is, the larger the reserves it is motivated to accumulate.

In summary, the literature on exchange-rate regime choice suggests that democratic countries are more likely to have high official reserve balances than authoritarian countries; the literature on developing countries' representation in the IMF suggests

15) For a regional comparison of IMF representation, see D. Rapkin and J. Strand. "Is East Asia Under-represented in the International Monetary Fund?' International Relations of the AsiaPacific 3 (2003), pp.1-28.

16) Table 4 in the next section contains the summary statistics of the IMF representation index, a indicator created to show how well a country is represented in the IMF, for countries selected for our study. The summary statistics tell us the same story as Rapkin and Strand: Some developing countries are over-represented, while others are under-represented. 
that countries that are under-represented in the IMF are more likely to accumulate larger foreign-exchange reserves than well-represented countries.

\section{Empirical Analysis}

To test the propositions outlined in the previous section, we take a snapshot of approximately ninety non-OCED countries' reserve holdings in 2002 and run regressions to estimate the effects of select economic and non-economic variables on reserve accumulation. ${ }^{17)}$ The exact number of countries included in our research varies slightly from estimation to estimation due to data availability.

A cross-sectional study is better suited for capturing the effect of spatially varying variables than a longitudinal study, while the latter is better at capturing the effect of temporally varying variables than the former. Among the two, a cross-sectional study is particularly appropriate for our research, since our variables of interest-democracy and representation in the IMF-vary extensively in spatial terms, but not in temporal terms. This is not surprising because political regimes and status in international organizations, while usually different from one country to another, do not usually vary much in a decade or two.

Cross-sectional research is often criticized for not being able to tell us the direction of causality. While we will not discuss the validity of such criticism here, suffice it for us to say that the direction of causation is not ambiguous in our case. ${ }^{18)}$ There is no known evidence, let alone logical argument, to suggest that reserve holdings somehow causally determine a country's political regime, GDP, or its IMF quota, which was previously decided by the IMF. ${ }^{19)}$

17) This means that Japan and South Korea are not included in the sample. Also not in the sample is Taiwan; its omission is due to data unavailability.

18) For a defense against such critique, see R. Jackman. "Cross-National Statistical Research and the Study of Comparative Politics." American Journal of Political Science 29 (1985), pp.161-182.

19) The size of a country's reserve holdings is one of the factors the IMF examines when it decides a quota for the country when the country becomes a member or during quota increases. Since quota determination and previous quota increases took place prior to 2002, it is not possible that a country's reserve holdings in 2002 somehow influenced the size of its quota, which had been set earlier. 


\section{Data and Variables}

Economic data as well as data on IMF quotas are from the IMF's 2004 report, "Quotas-Updated Calculations." Data on exchange-rate arrangements and capital controls are from the IMF's Annual Report of Exchange Arrangements and Exchange Restrictions. Data used to create the democracy variable is from Polity IV.

The dependent variable is the log of official reserves in 2002 measured in million SDRs. A number of factors are expected to affect its magnitude. First, there is the size of the economy: the larger the economy is, the more reserves it accumulates. According to the mercantilist argument, a country that values exports is likely to increase reserve holdings to keep the exchange rate at the level that best serves the country's interests. However, it is hard to measure with precision how much a country values exports. We divide a country's current account receipts by GDP and use it as a crude but straightforward proxy of the importance that the country attaches to exports. ${ }^{20}$ According to the precautionary-demand argument, a country's reserves are also likely to increase with the country's vulnerability to balance of payments shocks. Our variable for a country's vulnerability to external shocks is the log of the variability of netcurrent receipts and net-capital flows during the 1990-2002 period, measured as a standard deviation from centered 3-year trends. Additionally, exchange-rate arrangements and capital control are also likely to affect the level of official reserves. Specifically, flexible exchange-rate arrangements and tight capital controls are likely to reduce the need for reserve hoarding. We use a dummy to indicate floating exchange rate arrangements and the number of restrictions placed on capital transactions to indicate the tightness of capital controls.

As for our political and institutional variables, we subtract a country's AUTOC score in the Polity $\mathbb{I}$ dataset from its DEMOC score to obtain the democracy variable, as is commonly done in many political science studies. To measure a developing country's degree of under-representation in the IMF, we divide the country's share of total IMF quotas by its share of the world's GDP. When a country is neither under-represented nor over-represented, the variable takes the value of 1 . When the country is underrepresented-i.e. its share of total IMF quotas is smaller than its share of global GDPthe variable takes a value smaller than 1.

20) The "Quotas-Updated Calculations" report, from which economic data is from, uses multi-year averages whenever possible. Given the volatility of developing countries' economy from year to year, multi-year averaging is a sound approach and is therefore adopted in this paper whenever data allows. 
〈Table 4〉 Descriptive Statistics of Variables

\begin{tabular}{l|c|c|c|c}
\hline \multicolumn{1}{c|}{ Variable } & Mean & Std.Dev. & Min & Max \\
\hline Reserves in 2002, logged & 6.85 & 1.83 & 3.37 & 11.01 \\
\hline GDP, logged & 8.99 & 1.72 & 5.11 & 12.86 \\
\hline Current receipts ('98-02), relative to GDP & 0.49 & 0.30 & 0.07 & 1.85 \\
\hline $\begin{array}{l}\text { Variability of current receipts and net capital lows } \\
\text { ('90-'02), logged }\end{array}$ & 5.50 & 1.59 & 1.64 & 8.94 \\
\hline Floating exchange rate arrangement & 0.51 & 0.50 & 0 & 1 \\
\hline Number of capital control restrictions & 8.48 & 4.10 & 0 & 13 \\
\hline Democracy & 2.80 & 6.39 & -10 & 10 \\
\hline Representation in the IMF & 4.46 & 3.80 & 0.52 & 21.17 \\
\hline
\end{tabular}

* Reserves, GDP, current receipts, and capital flows are measured in million SDRs.

\section{Results}

〈Table 5〉 Determinants of Official Reserve Holdings

\begin{tabular}{l|c|c|c}
\hline \multicolumn{1}{c|}{ Variables } & Model 1 & Model 2 & Model 3 \\
\hline GDP & $0.418^{* *}$ & $0.637^{* * *}$ & $0.417^{* *}$ \\
\hline Exports & 0.298 & 0.585 & 0.486 \\
\hline Vulnerability & $0.555^{* * *}$ & $0.321^{*}$ & $0.472^{* * *}$ \\
\hline Flexible Exchange Rate Regime & & 0.241 & 0.168 \\
\hline Capital Control & & -0.082 & -0.071 \\
\hline Democracy & & & $0.040^{* * *}$ \\
\hline MF Representation & & & $-0.065^{* *}$ \\
\hline Constant & -0.119 & -0.822 & 0.561 \\
\hline No. of Obs. & 99 & 90 & 90 \\
\hline Adj. R-squared & 0.717 & 0.770 & 0.797 \\
\hline
\end{tabular}

Notes: 1) Exports, vulnerability, and GDP are logged.

$2{ }^{*}, * *$, and $* * *$ denote significance at the $10 \%, 5 \%$, and $1 \%$ levels, respectively.

Table 5 contains results from three regression models. Model 1 is a base model with three main economic variables only. The first thing to notice is the adjusted R-squared, which is 0.717 . The base model explains over seventy percent of the variations in developing countries' reserve holdings. The GDP variable is both significant and positive across all three models, suggesting that a country with a large economy is likely to have larger reserve balances than a country with a small economy. The export variable is correctly signed, but not significant, in all models. This result is not supportive of the 
mercantilist argument. The vulnerability variable is correctly signed and statistically significant in all models, which is consistent with the precautionary demand argument. The results bear out the precautionary demand explanation, but not the mercantilist argument. It is notable that our results are consistent with Aizenman and Lee's findings. Their research has shown that the self-insurance motive has been the predominant factor in the recent reserve build-up, while the mercantilist motive has been much less significant. ${ }^{21)}$

Model 2 has two additional variables: flexible exchange-rate regime and capital control. The flexible exchange-rate regime dummy has an unexpected sign from a theoretical point of view; i.e. its positive sign implies that a country with a flexible exchange-rate regime is likely to accumulate larger reserves than a country with a fixed or intermediate regime. The variable is not statistically significant, however. The capital control variable is correctly signed, but it, too, is not significant.

Model 3 includes the variables of our primary interest. The democracy variable has a positive sign and is statistically significant, indicating that democracy affects reserve accumulation as hypothesized. On the other hand, the negative, and statisticallysignificant, sign of the IMF-representation variable indicates that over-represented countries - those with the value of the variable larger than 1-tend to have smaller reserve holdings, while under-represented countries - those with the value of the variable smaller than 1 -tend to increase reserve-holdings, even after major economic variables have been controlled for. The results bear out our notions that democratic countries are more likely to have high official reserve balances than authoritarian countries, and that countries that are under-represented in the IMF accumulate larger reserves than countries that are well represented.

How large are the effects of the two variables? The coefficients in Table 5 are unstandardized, making it difficult to understand with any readiness the relative importance of the independent variables. Table 6 contains standardized coefficients of all four statistically significant variables from Model 3. Standardized coefficients in Column 2 show how much a 1-standard deviation increase in each independent variable can change the dependent variable. Before standardization, the democracy variable appeared to be of little importance due to its small coefficient size; after standardization, one can see that its influence is actually far larger than its nonstandardized coefficients first suggested. Similarly, the IMF representation variable appeared of small importance but after standardization, the variable was shown to have

21) Aizenman and Lee (2005). 
a much larger impact than suggested by its non-standardized coefficient. The results suggest that, together with economic factors, political and institutional factors play an important role in reserve accumulation in the developing world.

〈Table 6〉 Relative Importance of Independent Variables (Model 3)

\begin{tabular}{l|c}
\hline \multicolumn{1}{c|}{ Variables } & $\begin{array}{c}\text { Standardized Coefficients } \\
\text { (Unstandardized Coefficients) }\end{array}$ \\
\hline GDP & $0.727(0.417)$ \\
\hline Vulnerability & $0.776(0.472)$ \\
\hline Democracy & $0.256(0.040)$ \\
\hline Representation in the IMF & $-0.257(-0.065)$ \\
\hline
\end{tabular}

\section{Conclusion}

In his 1999 Foreign Affairs article, "A Self-Help Guide for Emerging Markets," M. Feldstein warned emerging markets, "Neither the International Monetary Fund (IMF) nor a new global financial architecture will make the world less dangerous." ${ }^{22)}$ His advice, in one sentence, was: "Liquidity is the key to financial self-help." Developing countries seem to have taken his advice to heart. Between 1990 and 2002, developing countries as a whole increased their holdings of foreign exchange reserves more than fivefold. By holding as reserves the government bonds of developed nations, developing countries are now exporting capital to developed countries-principally to the United States.

Developing countries' reserve accumulation is troubling, however. The level of reserves held by monetary authorities in many developing countries is excessive, even by some of the strictest criteria proposed so far. Also, developing countries are incurring a substantial cost because they are essentially foregoing opportunities for higher-yield investments by holding foreign currencies and government bonds as reserves.

What explains this unprecedented surge in developing countries' official reserves, despite the huge cost? This paper has sought to answer this question. Drawing upon the literature on exchange rate-regime choice and developing countries' representation in the IMF, we hypothesized that democratic countries are more likely to have high official reserve balances than authoritarian countries, and that under-represented countries in

22) M. Feldstein. "A Self-Help Guide for Emerging Markets." Foreign Affairs (March/April 1999), p.93. 
the IMF are likely to accumulate larger foreign exchange reserves than well-represented countries. We tested the hypotheses through cross-sectional analysis of approximately ninety non-OCED countries. The results confirmed our expectations: democratic countries have higher official reserve balances than authoritarian countries; countries that are under-represented in the IMF accumulate larger reserves than countries that are well represented. How large are the effects of the two variables? The democracy and IMF-representation variables appeared of small importance before their coefficients were standardized, but, after standardization, they were shown to have a considerable impact.

Over the past several decades, political scientists have proposed explanations for various events and decisions in the areas of international money and finance but the rise in developing nations' reserve holdings has curiously escaped their attention. This paper is a first step in explaining the reserve-accumulation behavior of developing countries through consideration of political and institutional factors. It has shown that along with economic variables, a developing country's political regime and its representation in the IMF are important factors influencing reserve-accumulation behaviors. Future research should seek to improve our understanding of developing countries' reserve accumulation by exploring additional political and institutional factors, as well as by going beyond cross-sectional analysis. 


\section{REFERENCES}

Aizenman, J. and J. Lee. "International Reserves: Precautionary vs. Mercantilist Views, Theory and Evidence." IMF Working Paper WP/05/198 (October 2005).

Aizenman, J. and N. Marion. "The High Demand for International Reserves in the Far East: What's Going On?” NBER Working Paper 9266 (2002).

Baker, D. and K. Walentin. "Money for Nothing: The Increasing Cost of Foreign Reserve Holdings to Developing Nations." Center for Economic and Policy Research. (2001).

Bernhard, W. and D. Leblang. "Democratic Institutions and Exchange Rate Commitments." International Organization 53 (1999).

Bird, G., and R. Rajan. "Too Good to be True?: The Adequacy of International Reserve Holdings in an Era of Capital Account Crises" CIES Discussion Paper 0210 (Australia: University of Adelaide, 2002).

Broz, J. and J. Frieden. "The Political Economy of International Monetary Relations." Annual Review of Political Science 4 (2001)

Cohen, B. "The Triad and the Unholy Trinity: Lessons for the Pacific Region," in R. Higgott, R. Leaver, and J. Ravenhill (eds.), Pacific Economic Relations in the 1990s: Conflict or Cooperation? Boulder, CO: Lynne Rienner, 1993.

Dean, J. and R. Rajan. "Why and Whither China's Reserves?: Motives, Costs, Consequences and Putative Policies." manuscript (2004)

Dooley, M., D. Folkerts-Landau and P. Garber. "An Essay on the Revived Bretton Woods System.” NBER Working Paper 9971 (2003)

Fee, W. L. "International Reserve Accumulation in East Asia." International Review of Business Research Papers 2-2 (August 2006).

Feldstein, M. “A Self-Help Guide for Emerging Markets.” Foreign Affairs (March/April 1999).

Frieden, J. "Invested Interests: The Politics of National Economic Policy in a World of Global Fiance.” International Organization 45 (1991).

Hauner, D. "A Fiscal Price Tag for International Reserves." IMF Working Paper WP/05/81 (April 2005).

Higgins, M. and T. Klitgaard. "Reserve Accumulation: Implications for Global Capital Flows and Financial Markets." Current Issues in Economics and Finance 10 (September/October 2004). 
Horne, J. and D. Nahm, "International Reserves and Liquidity: A Reassessment." Macquarie Economics Research Paper 5 (2000).

International Monetary Fund. "Quotas-Updated Calculations.” Prepared by the Financial Department. August 2004.

Jackman, R. "Cross-National Statistical Research and the Study of Comparative Politics.” American Journal of Political Science 29 (1985).

Lai, K., D. Ho, and D. Tam. "International Reserve Holdings-Are Financial Centers Different?” Hong Kong Monetary Authority Quarterly Bulletin (September 2004).

Leblang, D. "Domestic Political Institutions and Exchange Rate Commitments in the Developing World.” International Studies Quarterly 43 (1999).

Leblang, D. "To Devalue or to Defend? The Political Economy of Exchange Rate Policy." International Studies Quarterly 47 (2003).

Rapkin, D. and J. Strand. "Is East Asia Under-represented in the International Monetary Fund? International Relations of the Asia-Pacific 3 (2003).

Rapkin, D. and J. Strand. "Developing Country Representation and Governance of the International Monetary Fund." World Development 33-12 (2005).

Rodrik, D. "The Social Cost of Foreign Exchange Reserves." Paper prepared for presentation at the American Economic Association meetings in Boston, January 2006.

Sachs, J., et. al. "Financial Crises in Emerging Markets: The Lessons from 1995" Brookings Papers on Economic Activity 1 (1996)

Setser, B. “RGE Global Reserve Watch: Q2 2006.” RGE Monitor (2006).

Summers, L. "Reflections on Global Account Imbalances and Emerging Markets Reserve Accumulation.” L.K. Jha Memorial Lecture, Reserve Bank of India, India, 2006. http://www.president.harvard.edu/speeches/2006/0324_rbi.html (Access date: October 2006)

Yoon, D. R. and Y. Rhee. The Demand for and Optimal Management of International Reserves in Korea (in Korean). Seoul: Korea Institute for International Economic Policy, 2005.

"International Foreign Exchange Reserves: An Update." Capital Flows Monitor, June $23,2000$. 